\title{
LINGUAGENS DE SÍNTESE VISUAL EM PROCESSO DE DNA: ESTUDO DE CASOS DE MARCAS DE MODA PRAIA EM PORTUGAL
}

\section{LANGUAGES OF VISUAL SYNTHESIS IN THE PROCESS OF DNA: CASE STUDIES OF PORTUGUESE BEACHWEAR BRANDS}
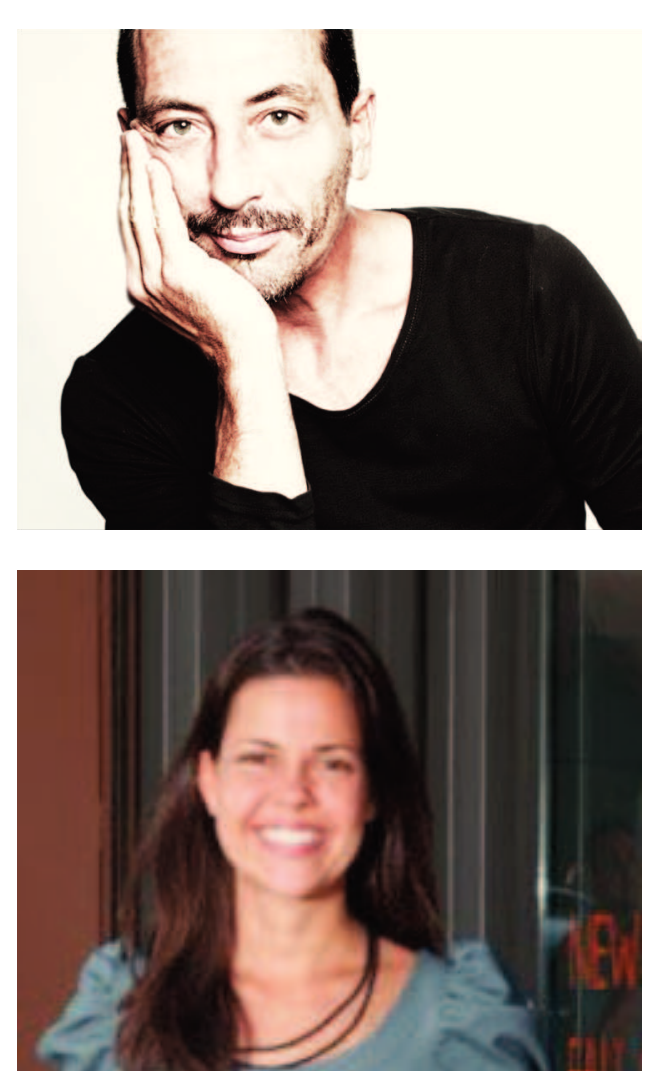

\section{Fernando Jorge Matias Sanches Oliveira}

Professor Doutor em Design pela FA/UL

fernando.oliveira@iade.pt

\section{Juliana Lima Mendonça}

Mestre EM Branding e Design de Moda. IADE-U/UBI jlimamendoca@gmail.com

\section{RESUMO}

O presente artigo objetiva uma reflexão sobre os processos de simplificação da análise da identidade visual de marcas, por meio da aplicação de linguagens de síntese visual na compreensão desses sistemas. Pragmaticamente, o estudo foi aplicado ao mercado da moda praia em Portugal no intuito de diagnosticar as suas tendências e analisar a ligação entre a personalidade/DNA da marca e o sistema visual de quatro casos. Pode-se dizer que os resultados permitiram constatar que as linguagens de síntese visual aplicadas aos estudo da linguagem visual de uma determinada marca podem permitir ter um maior controle sobre esse universo visual, bem como sobre a implementação do seu DNA.

\section{PALAVRAS-CHAVE}

DNA de Marcas. Moda de Praia. Linguagem de Síntese Visual.

\section{ABSTRACT}

This paper aims to reflect on the simplification process of the analysis of brands' visual identity. That, through the application of visual synthesis 
languages for the comprehension of these systems. Pragmatically, the study applies to the fashion beach market in Portugal in order to diagnose trends and analyze the link between the brand's personality / DNA and the visual system in four cases studies. The results demonstrated that the synthesis of visual languages applied to the study a particular brand's visual language allows a greater control over the visual universe, as well as on the implementation of the brand's DNA.

\section{KEYWORDS}

Brand DNA. Beachwear. Language of Visual Synthesis.

\section{INTRODUÇÃO}

Este artigo reflete parte de uma prática realizada durante as pesquisas para desenvolvimento da dissertação de conclusão do Mestrado em Branding e Design de Moda intitulada "A Linguagem Visual na Moda de Praia: Imagem de Marca, Análise do beachstyle e estudo comparativo entre Portugal e Brasil." defendida em 2015 por Juliana Lima Mendonça sob orientação do Professor Doutor Fernando de Oliveira. Concretamente, este texto se refere ao processo utilizado para entender as marcas de moda de praia feminina portuguesas de referência, no intuito de posicionar e desenvolver a Linguagem de Marcas de beachwear.

O objetivo desse projeto e deste artigo foi de perceber a evolução de cada uma das marcas no espaço temporal que inicia e fecha a temporada. Durante seis meses foram recolhidos suportes do desenvolvimento da comunicação e da identidade visual das marcas, os quais foram posteriormente organizados em suportes visuais sintetizados a partir dos modelos de construção e análise propostos por Oliveira (2015), permitindo entender os elementos da linguagem visual como reflexo do DNA e posicionamento da marca, bem como a importância do design gráfico/visual no controle da parte visual da Identidade e no contributo para a percepção da linguagem da marca.

Considera-se relevante para o estudo aqui apresentado destacar a importância do design gráfico/visual como ferramenta de gestão de marca. Assim, deu-se ênfase às áreas de identidade visual de marca na análise de elementos componentes da mesma. Como objetivo secundário, buscou-se gerar maior conhecimento sobre os elementos visuais e utilizar uma representação gráfica com fins de permitir uma análise mais adequada, aumentando a percepção sobre a linguagem visual de marca.

As linguagens de síntese visual/diagramas são apresentadas aqui como um processo de projeto que emerge a partir de um modelo de representação de sistemas de identidade visual (OLIVEIRA, 2015) e que se apoia na informação dada pelos suportes produzidos para a comunicação de uma determinada marca. Para tal, foi significativo aplicar as teorias de representação gráfica das linguagens de síntese visual, as quais que permitem uma leitura mais correta dos suportes visuais com o intuito de melhorar a tomada de decisão, na análise de marcas de moda praia em Portugal.

\section{OBJETIVOS}

O objetivo deste artigo foi o de refletir os resultados da aplicabilidade do modelo proposto por Oliveira (2015) no estudo da a linguagem visual de marcas portuguesas femininas de beachwear. Também intentou-se perceber se as linguagens de síntese visual ajudam no processo de análise e construção dos sistemas visuais de marca e a importância dos elementos visuais do sistema mencionado.

\section{METODOLOGIA}

Este estudo que aqui é apresentado foi sustentado por uma metodologia baseado na afinidade entre os seus vários intervenientes. Por meio de uma 
abordagem não intervencionista, optou-se por uma revisão e crítica da literatura, com o objetivo de relacionar conceitos e teorias relacionados com a área de estudo. Os estudos de caso foram introduzidos para conectar a teoria com a prática, introduzindo um elemento chave ao processo de design e influenciando a resposta à questão da investigação. Através de uma metodologia interventiva, foi introduzido o modelo nas atividades com o objetivo de perceber se o modelo e as linguagens de síntese visual facilitavam a tomada de decisão na análise de linguagens visuais das marcas de moda.

\section{QUESTÃO DA INVESTIGAÇÃO}

No contexto deste trabalho de investigação a questão que foi levantada era focada na utilidade das síntese visuais na compreensão de sistemas de identidade visual. Em termos concretos ficou cristalizada na pergunta: (1) as linguagens de síntese visual/diagramas podem ser úteis na leitura e diagnóstico da linguagem visual de uma determinada marca? Paralelas à esta questão, também procurouse elucidar neste artigo: (2) Qual a representação adequada à clarificação desses sistemas de identidade visual? e (3) Que elementos compõem esses sistemas e qual a maneira mais correta de os representar para permitir a comparação?

\section{ENQUADRAMENTO TEÓRICO}

\subsection{MARCA}

Parecem existir várias maneiras de explicar e tentar definir o que é uma marca. É possível, inclusive, observar uma certa confusão com o uso da palavra marca, pois muitas pessoas usam-na para referir-se apenas à marca gráfica de uma determinada empresa ou produto (RAPOSO, 2008). De acordo com Carvalhal (2014), ao falar nesse termo estamos a falar da organização, história, trajetória, fama, conceito, identidade, valores e toda significação que adiciona magia e personaliza a alma de um produto. Segundo Martins (2006) marca é a união de atributos tangíveis e intangíveis, que geridos de forma adequada criam influência e valor.

Uma marca é um sistema integrado de ações que envolvem eficiência na preparação, entrega e manutenção dos atributos materiais e de imagem do negócio. De acordo com Martins (2005), a percepção positiva ou negativa daquilo que os consumidores recebem materializa-se no sinal. A sustentação, qualidade e continuidade das relações positivas que sejam estabelecidas acabam por consolidar o sinal -como a melhor referência de identificação e, provavelmente, de repetição de consumo; ou seja, fidelização.

De acordo com Cobra (2007), a marca é mais que um produto e/ou serviço, representando também um estilo de vida. É aqui que o conceito de branding se insere. Este está diretamente ligado à administração da marca, surge com o propósito de levar as marcas além da sua natureza econômica, fazendo com que estas passem a fazer parte da vida dos consumidores e da sua cultura. Nesse contexto cultural, as marcas emergem como um valor, traduzem personalidades e afirmação de identidades pessoais, o que destaca o branding como fundamental (WHEELER, 2012).

\subsection{IDENTIDADE DE MARCA}

De acordo com Ruão \& Farhangmer (2000), a identidade da marca deve integrar todo o conjunto de características que lhe são específicas; resultantes da sua história, dos seus valores, das suas propriedades, do seu aspecto físico e da relação com os seus públicos, que são, em síntese, as características tangíveis e intangíveis atribuídas às marcas. Trabalhar sobre a identidade de uma marca é buscar as invariantes sobre as variações, a permanência sob as rupturas, as mudanças, a inovação. Contudo, para o funcionamento da identidade de uma marca também é essencial uma comunicação adequada, traduzindo a identidade em identidade 
visual, definida por Olins (1995) como estilo visual - visual style.

O sistema de identidade visual é, assim, a linguagem visual da marca, a qual Lupton e Phillipps (2011) definem como algo mais amplo do que a marca gráfica; um sistema de elementos concretos oriundos do design gráfico, tais como: cores, formas, imagem, tipografia, texturas, padrões e/ou materiais. Olins (1995) faz alusão à existência de elementos básicos do sistema que define por: nome (sub nomes, se for apropriado), símbolo, tipografia (oficial e de apoio, se for apropriado), e cor (es). Os elementos que apoiam o sistema são identificados como complementares; são eles: imagética; forma; movimento e som, que não é um elemento visual, mas que faz a passagem deste para outros sentidos.

Os componentes visuais são maioria no que diz respeito à expressão da identidade da marca. Assim, a função do design visual/gráfico assume particular importância e torna-se relevante para a linguagem visual de uma marca, pois os elementos que a constituem são pelouro da disciplina referida. A origem do tema deste artigo consiste numa reflexão e combinação entre duas áreas do conhecimentos do design. Os sistemas de identidade visual e os sistemas de síntese informação visual ou os diagramas, popularizados pelos termos "infografia", "design de Informação" ou "visualização de informação".

\subsection{LINGUAGENS DE SIINTESE VISUAL: ASPETOS SOBRE A REPRESENTAÇÃO NOS DIAGRAMAS}

Para Lupton e Philps (2008), um diagrama consiste na representação gráfica de uma estutura, processo ou situação. Eles podem descrever anatomias, hierarquias e até fluxos de ideias e sua principal característica é evidenciar as relações entre diferentes partes de um todo. De acordo com este raciocínio é possível afirmar que a linguagem visual tem capacidade de representar qualquer fenômeno, mas também deve permitir uma visão macro e micro do sistema de identidade visual. Joan Costa (1998), assume esta temática através do termo "La Esquemática" que utiliza os suportes histórico-culturais da comunicação gráfica para produzir conhecimento através da passagem de informação tratada e visualmente sintetizada.

Tufte parece ter uma importância acrescida no mundo do Design de Informação, uma ideia que é assumida por Lupton e Phillips (2008, p. 199). Apesar de Tufte (2009, p. 38) sugerir várias abordagens à explicação visual de um qualquer fenômeno, há algumas menções que faz sobre práticas corretas para a excelência da representação visual sintetizada. Os seus Principles of graphic Excelence (Ibid) falam que esta representa um design bem desenvolvido apoiado em informação interessante e complexa, comunicada com clareza, precisão e eficiência.

Tufte (2007) formula alguns princípios sobre o design de representação da informação que defende serem as bases dos gráficos de excelência. O primeiro é a comparação, através dos contrastes e das diferenças. O segundo é a causalidade, o mecanismo, a estrutura sistemática e a explicação visual. O terceiro consiste na análise multivariada e na visualização de mais de uma variável. O quarto princípio é a integração de evidência que pretende uma relação entre os elementos - palavras, imagens, números. O quinto envolve a documentação sobre a informação disposta. O sexto e último princípio afirma que o conteúdo é o mais importante (lbid).

No tópico seguinte serão apresentados quatro estudos de caso de discursos visuais de marcas de moda praia portuguesas sistematizados a partir de esquematizações e diagramas fundamentados em Oliveira (2015) e Tufte (2007). Os diagramas foram utilizados como apoio à representação visual do modelo como metodologia e como parte integrante do processo de design. Assim, sugere-se que a aplicação desta metodologia facilita a percepção geral - consciência de um todo visual -, definindo com maior grau de solidez a apresentação das marcas às suas audiências. 


\section{ESTUDOS DE CASO}

\subsection{O PROCESSO DE VISUALIZAÇÃO DO DNA}

Os estudos de caso tiveram o objetivo de analisar as marcas concorrentes para a definição das linguagens visuais das mesmas e, com isso, poder comparar e posicionar as referidas marcas percebendo a diferenciação existente entre as mesmas. Para esta análise foi utilizado o modelo para diagnóstico desenvolvido por Oliveira (2015) que pode ser visualizado na figura 1. Esse pretende representar os componentes da linguagem visual das marcas e surge como uma maneira de esquematiza-la por meio da estruturação visual dos seus elementos num todo (OLIVEIRA, 2015).

O modelo é genérico e representativo e tem o intuito destacar os elementos importantes para o sistema de linguagem visual, gerando um processo de orientação para a colocação do material visual de uma marca num ambiente controlado, evidenciando as variáveis que podem não estar em conformidade com o modo visual pretendido. Para a correta utilização do modelo, é suposto que todo o material visual recolhido seja disposto num único suporte, de maneira ordenada, devidamente codificado com as informações que definem a tipologia dos elementos e que permitem a interpretação do sistema de identidade visual.

Figura 1. Modelo linear final para a representação genérica dos elementos Constituintes da Linguagem Visual de uma marca

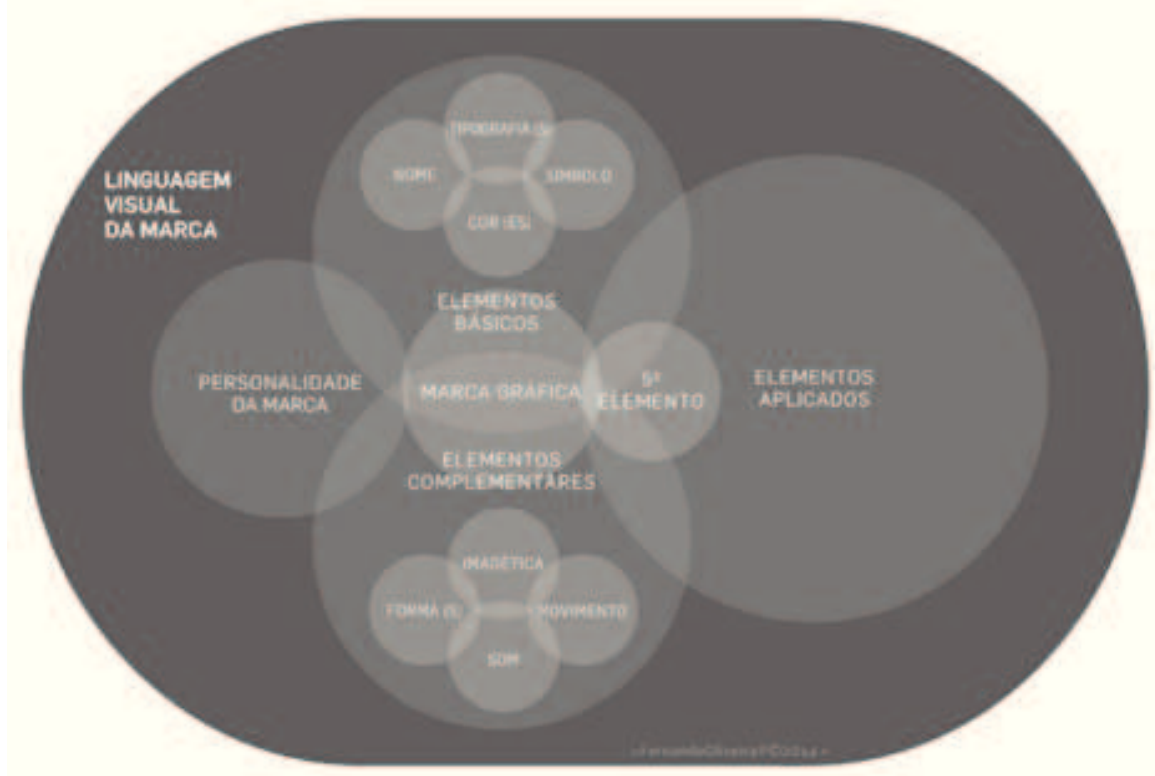

Fonte: Oliveira, 2015.

O mesmo material visual deve ter por base os materiais existentes sobre a Identidade a estudar (elementos aplicados/aplicações ou através dos manuais ou brandbook) que por sua vez devem ser organizados num suporte de maneira a clarificar a personalidade da marca em palavras chave, a marca gráfica, os quatro elementos básicos (nome, símbolo, tipografia e cor) e os elementos complementares; mostrando a sua representação gráfica e descrevendo, sinteticamente, o que essa representa face à marca abordada. Pensa-se ser importante mencionar que a ordem de organização dos elementos no suporte pode necessariamente deve obedecer à ordem aqui indicada e que existem sistemas que não são compostos por todos os elementos aqui referenciados.

Para obter uma melhor representação gráfica e melhor análise, a síntese visual 
referida deve ser apoiada nas ideias de Tufte (2009), que afirma ser possível destacar o design adaptado ao conteúdo e o máximo de informação no mínimo de espaço possível. O mesmo autor destaca a possibilidade de utilização dos elementos gráficos para explicar a informação tais como: setas, linhas, escalas, grelhas, caixas, legendas e destaques (Ibid). Tufte também aponta o paralelismo, pois este conecta os componentes por semelhança e sincronização, revelando padrões e desvios de modo a simplificar a comparação e com ela a decisão, a qual faz referência à percepção e ao controle da realidade de um determinado sistema visual (lbid).

\subsection{MARCAS DE MODA PRAIA NO MERCADO PORTUGUÊS}

Para o presente estudo foram destacadas algumas marcas de moda praia que estão a conquistar público e a atingir grande expressividade em território nacional (Portugal) e que já começaram a ter alguma repercussão internacional. Para melhor compreensão do universo de cada uma dessas marcas, foi realizado um suporte visual que sintetiza o mood - em inglês, clima ou modo - e a linguagem visual de uma determinada marca, codificando esse sistema através dos principais elementos que compõe a sua identidade visual.

\subsubsection{MARCA CANTÊ LX}

A marca Cantê foi criada em 2011 e desde o início do seu lançamento no mercado, a marca é bastante comunicativa nas redes sociais. A presença da marca alcançou maior força nos dois últimos anos. Hoje a sua fanpage na rede social Facebook tem 65 mil seguidores e o perfil da rede social Instagram conta com 23 mil seguidores. O público alvo da marca é a população feminina, jovem e romântica. A marca materializa esta ideia recorrendo ao uso de elementos delicados. Os produtos apresentam modelagem simples, sendo pouco ousados. Os detalhes das peças também traduzem o romantismo, com a presença de muitos laços e apliques em tecido e a linguagem da marca emana um pouco do estilo francês.

Foi possível chegar à essa conclusão através de informações provenientes de fontes relacionadas com a marca, bem como a partir da análise dos materiais reunidos, os quais deram origem ao moodboard de síntese da linguagem visual da marca (Figura 2). Sobre este último, pode-se dizer que os elementos presentes neste sistema seguem o argumento da marca, tal como é possível de visualizar na figura 2 e como apresentar-se-á em seguida.

Figura 2. Linguagem Visual da Marca CANTÊ.

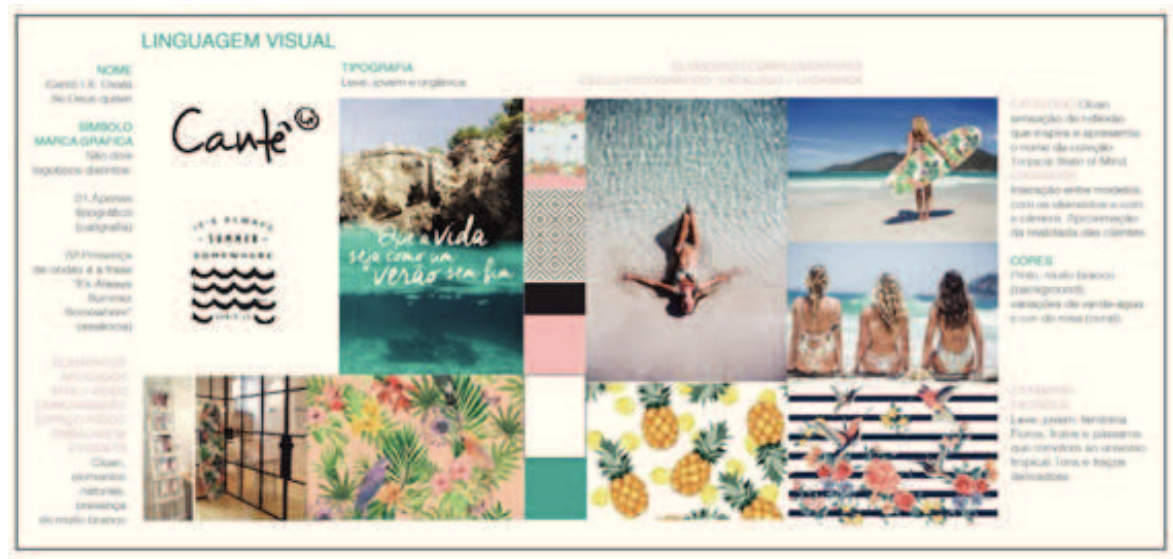

Fonte: Suporte de Síntese Visual desenvolvido por Juliana Lima Mendonça 
O nome estabelece ligação com a cultura francesa já referida. Apesar disso, utiliza a sigla " $L X$ " afirmando a cidade de origem da marca (Lisboa). A marca gráfica utiliza um tipo caligráfico denotando um produto cuidado, uma proximidade e um look casual. Por vezes surge uma espécie de selo ou etiqueta com motivos ondulados e com a frase "It' s Always Summer Somewhere", que pode bem ser a tradução verbal da essência da marca. Esta representação gráfica é fechada com o nome Cantê LX e utiliza um tipo sem serifas. $O$ conjunto também tem o aspecto casual que está presente na marca gráfica.

Não se pode dizer que existe um símbolo nesta marca gráfica. O único elemento que pode ser considerado como tal são as formas onduladas presentes neste espécie de selo. A tipografia usada na comunicação tem o registo do tipo manuscrito da marca gráfica, denotando os mesmos princípios desta e reforçando a mensagem jovem e orgânica. Sobre a componente cromática, pode-se dizer que as principais cores usadas na marca são o preto e o branco. Na linguagem visual já é visível a presença de cores auxiliares, pois a comunicação da marca se faz por superfícies brancas com variações de verde-água e cor-de-rosa (coral), reforçando o toque feminino e delicado em toda expressão visual. Outras cores como amarelo, laranja, vermelho e roxo emergem em relação com a estação do ano em questão (Figura 2).

Sobre os elementos complementares se pode dizer que a imagética oscila entre a imagem conceitual e nos lookbooks, o que é uma prática comum em marcas de moda. A ambientação normalmente consiste em uma praia e a figura humana é apresentada muitas vezes de costas. O contraste é apurado e existe sempre a presença de água. Sobre os padrões, onde se incluem as formas, pode-se dizer que têm uma representação gráfica orgânica com ilustrações de frutos, flores e ambientes tropicais, bem como da fauna voadora deste clima.

O resultado visual consiste em superfícies super coloridas e super ilustrativas, por vezes misturadas com formas geométricas como riscas, as quais parecem seguir uma tendência para o verão de 2015. Todavia, apesar de este registo visual poder estar focado num limite temporal, o clima gerado pelas ilustrações parece estar em conformidade com a personalidade desta Marca. Sobre o som e o tom de voz a marca, é sólida face à personalidade pretendida. A música utilizada nos vídeos de lançamento da coleção de 2015 emana uma acústica analógica e uma voz calma e pausada que não canta, mas que fala e apela ao coração.

\subsubsection{MARCA LATITID}

Latitld é uma marca portuguesa de biquínis, trajes de banho e roupa de praia criada e lançada entre os anos de 2012 e 2013 (LATITID, 2015). Com um design que tem a intenção de revolucionar a visão tradicional dos biquínis e favorecer o corpo das Portuguesas, Latitid promete sofisticação e inovação no intuito de atingir um público exigente. Atualmente, a marca conta com mais de 26 mil seguidores na sua fanpage do Facebook e mais de 17 mil seguidores no seu perfil do Instagram. Os elementos que compõe o moodboard da marca (figura 3) transcrevem este universo sofisticado e apurado. O target da marca é a população feminina, jovem, com presença e estatuto elevado denota experiência e conhecimento. Esta mulher é, por vezes, arrojada e sexy, mas com um certo classicismo. Esta ideia é materializada na modelagem clássica, sofisticada e ousada dos seus produtos. 
Figura 3. Linguagem Visual da Marca LATITUD.

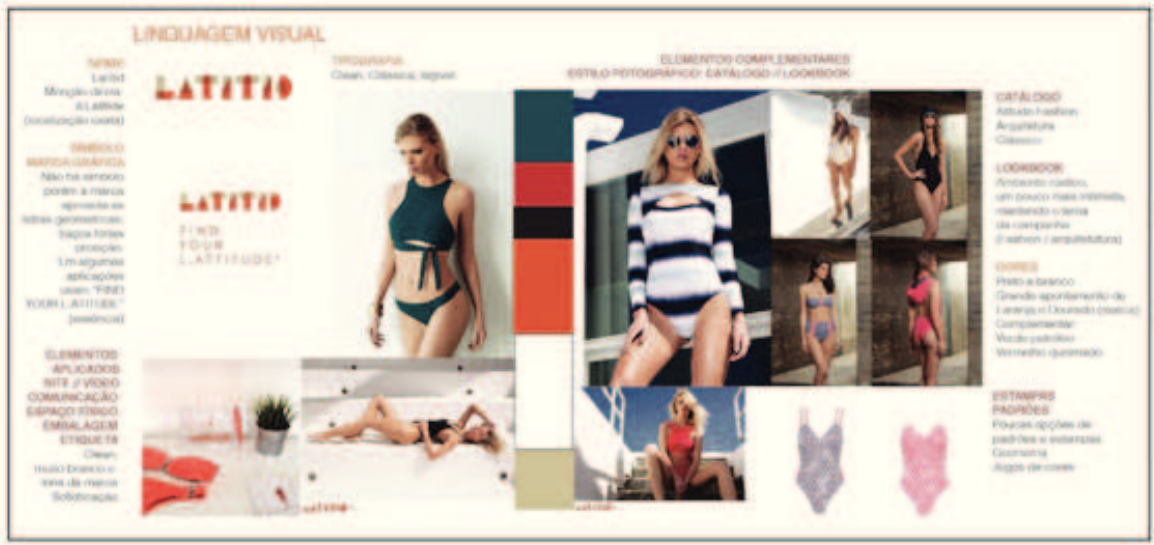

Fonte: Suporte de Síntese Visual desenvolvido por Juliana Lima Mendonça

Sobre a Linguagem da Marca (Figura 3), pode-se inferir que os elementos presentes no Sistema seguem a personalidade da marca semelhantemente ao descrito nos produtos. $O$ nome Latitid tem referência direta com a expressão "L'atitude" que significa localização exata e que cria a essência e a história da marca. As suas referências estão baseadas em localidades e na interpretações de tendências numa determinada região. $A$ assinatura das coleções é feita com a latitude do local que lhe serve de inspiração, como por exemplo as coordenadas da cidade do Porto $-51.5072 \mathrm{oN}$ - , cidade escolhida para o lançamento da primeira coleção, no ano de 2013.

A marca gráfica é tipográfica e utiliza um tipo original em que as letras são construídas por formas geométricas; como retângulos, triângulos e semicírculos; que sugerem um conceito de precisão e modernidade. Por vezes a marca gráfica é apresentada com a tagline "Find your L.atidid", que se relaciona com a essência da marca. Este registo é feito por um tipo neutro, sem serifas e com alguma elegância. É através destas mesmas características que se faz a comunicação escrita da marca. Uma vez que o objetivo da comunicação parece ser a de evidenciar a fotografia, sem ruídos.

Sobre as cores, a marca gráfica é constituída por um tom alaranjado e por um tom dourado. Estes, em conjunto com o fundo branco, detalhes em preto e algumas outras cores de apoio; como o verde-petróleo, o vermelho queimado e o azul-escuro; transmitem seriedade e sofisticação. Em relação aos elementos complementares, pode-se afirmar que o estilo fotográfico (imagética) apresenta uma atitude ousada com um toque de luxo. A imagem das campanhas leva a outros horizontes, pois deixa de lado a praia e apresenta uma mulher irreverente com toque cosmopolita e em ambientes de arquitetura modernas e minimalista.

Nas formas, a predominância também parece tender para o minimalismo. O produto tem um design elaborado, mas existe uma tendência para o tecido liso. Os únicos padrões existentes são geométricos e apresentam jogos de duas cores. O movimento pode ser caracterizado pela calma, transmitindo seriedade e tranquilidade e classicismo. Na marca gráfica este movimento é mecanizado e geométrico, possivelmente no intento de simbolizar um encaixe perfeito. $O$ som que acompanha as últimas coleções é de estilo pop-rock, o que parece disruptivo com a personalidade da marca. Contudo, é um som forte e dinâmico e poderia sugerir-se que o som possui ligação com a estética de alguns dos produtos da marca.

\subsubsection{MARCA PAPUA}

Papua apresenta posicionamento jovem e irreverente. A sua comunicação dirige-se à uma mulher alternativa e contemporânea. Os elementos visuais, o 
estilo fotográfico, o formato e as composições apresentam um estilo inovador e ousado. A marca exclusiva foi criada em Portugal em 2012. As coleções são criadas com uma filosofia distinta, inspiradas sempre em lugares exóticos, belas praias, música e arte (PAPUA, 2015). Papua apresenta preocupação e comprometimento pela qualidade dos produtos, o que é notável nos tecidos e acabamentos. A contemporaneidade e exclusividade parecem ser alcançadas pelo design e pela exclusividade.

Figura 4. Linguagem Visual da Marca Papua.

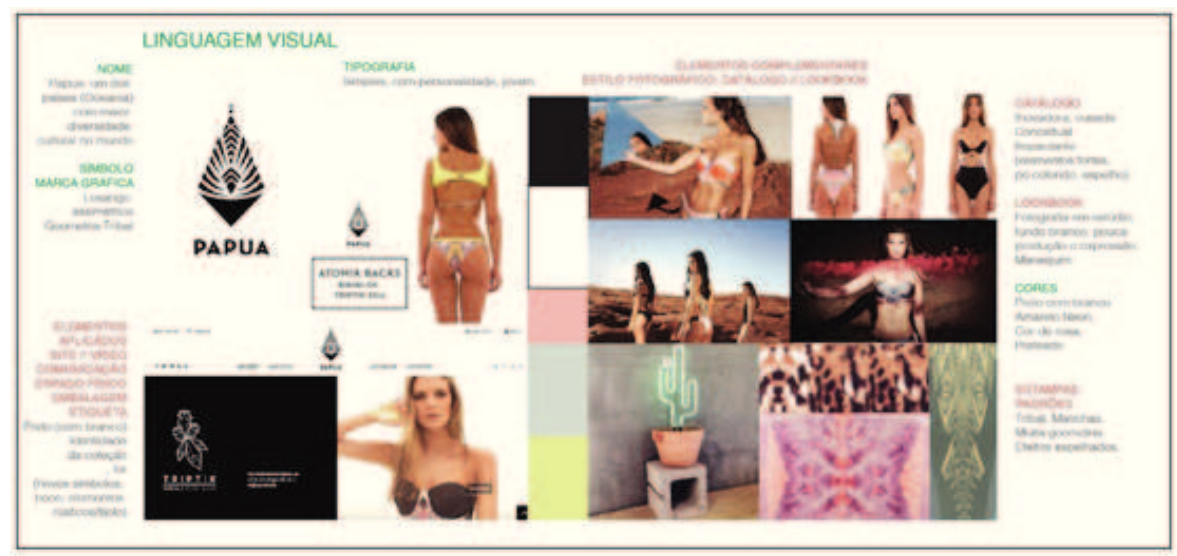

Fonte: Suporte de Síntese Visual desenvolvido por Juliana Lima Mendonça

A análise da linguagem visual da marca (Figura 4) permitiu relacionar o sistema visual com a essência e personalidade da marca. Os elementos visuais refletem um estilo ousado com ligações às culturas indígenas e à noção de tribo, o que é notado no próprio nome da marca, que utiliza parte do nome do país Papua Nova-Guiné. Não há constatação de que o nome da Marca derivou desta região, mas esta característica condiz com o DNA da marca, sendo possível estabelecer tal ligação. A ideia também parece presente no símbolo da marca gráfica. O elemento é composto por um losango com características de simetria e de geometria tribal, similar às ilustrações utilizadas nas tatuagens oriundas dos povos do Pacífico Sul. A composição remete ao misticismo e coincide com a personalidade da marca.

A tipografia usada não tem serifas e apresenta registos de geometria, o que lhe confere personalidade e a assemelha ao símbolo. A marca gráfica é desenhada em preto e branco, de modo a ser combinada com cores auxiliares referentes às coleções que se alteram conforme às tendências. A marca também explora o preto e branco nos produtos, diferenciando-se das demais marcas do segmento moda praia. As cores complementares são luminosas e exprimem a personalidade e a jovialidade da marca, introduzindo a relação com as tendências de moda.

Nos elementos complementares também seguem a personalidade da marca. $O$ estilo fotográfico parece ser inovador, pois não apresenta o produto no contexto convencional, ou seja, não utiliza a praia como cenário das imagens. A campanha é conceitual e apresenta elementos fortes como o pó colorido e espelhos.

As formas, que se traduzem nos padrões, condizem com a identidade visual da marca e com o conceito escolhido para a coleção. Os motivos tribais, a geometria e os efeitos que parecem a pele de animais garantem a relação conceitual do sistema. O movimento está presente no próprio símbolo da marca, uma vez que as linhas que o compõem parecem sugerir essa característica. Quanto ao som, a marca recorre a um registo contemporâneo apoiado em vozes femininas e sensuais com uma base musical de estilo "tecno" ou digital. Isto posiciona a marca na atualidade, mas que não parece estar diretamente fundado em seu DNA. 


\subsubsection{MARCA VOKE}

Da cidade para a praia, de Lisboa para o mundo. É assim que Voke se apresenta em seu site oficial (VOKE, 2015). De acordo com informações do mesmo suporte, a Marca foi criada para ocupar um posicionamento diferente e associar conforto e descontração a um lifestyle irreverente e divertido. A marca tem um objetivo definido no produto: peças originais. Lançada no verão de 2014, obteve prontamente modelos esgotados. Hoje, a marca possui mais de 20 mil fãs no Facebook. Tal como o nome dos produtos indica (11a.m, 3p.m, e assim por diante) a coleção Primavera/Verão 2015 da marca sugere que há trajes para todos as horas do dia.

De acordo com a síntese da Linguagem Visual da marca, figura 5, é possível afirmar que Voke apresenta um estilo arrojado, com produtos e modelagens mais ousadas e sexys, atingindo assim um público de mulheres jovens, urbanas e confiantes (VOKE, 2015). Os elementos do sistema acompanham a personalidade da marca. $O$ nome não tem tradução, mas essência apela à uma atitude irreverente, ativa e provocatória. A marca gráfica é apenas tipográfica e o tipo utilizado não tem serifas, mas apresenta um corte horizontal (espaçamento que faz a ruptura da palavra horizontalmente) e uso de diferentes pesos (ligth e bold), além da cor verde-água.

A tipografia da comunicação é maioritariamente a mesma que compõe a marca gráfica, mas utilizada sem cortes. Existe, contudo, alguma comunicação pontual que faz uso de outros tipos expressivos com características mais Fun e Pop e que também se relacionam com a ideia de ruptura que a marca projeta. A cor verde água é bastante característica na linguagem visual, presente na marca gráfica e em diversas aplicações. Contudo, há cores complementares, como laranja, preto e branco.

Figura 5. Linguagem Visual da Marca VOKE.

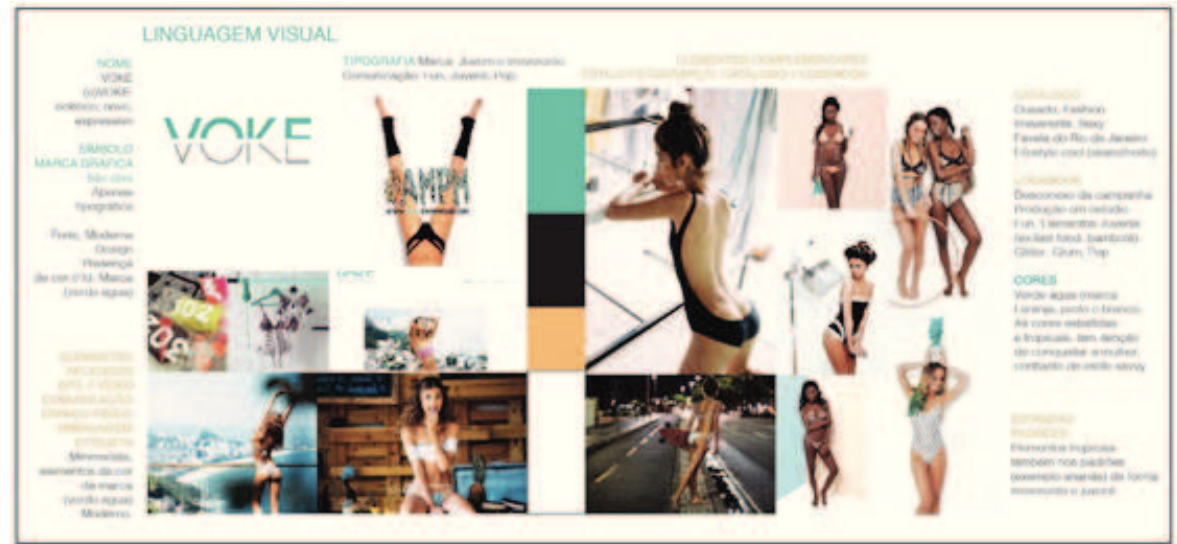

Fonte: Suporte de Síntese Visual desenvolvido por Juliana Lima Mendonça

A tipologia fotográfica conceitual é ousada e sexy. A sessão fotográfica foi realizada numa favela do Rio de Janeiro, apresentado a irreverência presente no DNA da marca, para além do lifestyle cool. Já o estilo fotográfico do lookbook surge com fundos lisos para destacar o produto. A ligação entre os dois estilos parece ocorrer pelo registo ousado das modelos. Na forma, a marca explora cores lisas, na maioria das vezes com padrões apenas em detalhes. Todavia, é possível observar que algumas estampas apresentam elementos tropicais, os quais ligam-se aos ambientes quentes. O movimento é dinâmico por ruptura. Esta é uma percepção presente na marca gráfica e na postura das modelos. O som é caracterizado por um registo digital, repetitivo e voz feminina, o que sugere um universo de audiência feminina e jovem. 


\subsubsection{A REPRESENTAÇÃO GRÁFICA DAS LINGUAGENS VISUAIS DAS MARCAS PORTUGUESAS DE MODA PRAIA: ANÁLISE COMPARATIVA.}

Como análise comparativa proveniente do estudo realizado, pode-se inferir que as marcas estudadas têm posicionamentos diferenciados no seu DNA bem como no seu Sistema Visual, o que é visível na grande maioria dos tópicos. Isso implica que as marcam se apresentem como alternativas distintas aos diferentes públicos femininos e jovens no segmento moda praia.

Em relação ao nome, as marcas estudadas revelam posicionamentos distintos que estabelecem uma ligação à personalidade diferenciada de cada uma das mesmas. Enquanto Canté LX parece ser uma denominação de origem francesa, remetendo ao romantismo e à delicadeza, o nome Latitid tem uma referência mais ampla no que envolve localização geográfica, o que implica que a marca se baseia no desenvolvimento de produtos sofisticados a partir da interpretação de diferentes lugares. Papua possui nome oriundo do Pacífico, revelando um espírito aventureiro e alternativo, com ligação à cultura indígena, meio-ambiente e a preservação de culturas. Por fim, o nome é o que se pode denominar designação aleatória e apela à atitude irreverente e provocatória da marca.

Nas marcas gráficas também é possível constar a diferenciação entre o DNA de cada uma das marcas de moda. Canté LX tem características caligráficas que remetem à casualidade, mas também a um espírito livre e delicado. Existem algumas referências simbólicas ao mar e às ondas que são a base dos produtos da marca. A marca gráfica de Latitid é tipográfica com registo de originalidade, pois é uma construção com base geométrica que sugere sofisticação e modernidade. A relação com os países do Pacífico e com o seu universo visual tem ligação direta com a marca gráfica de Papua. O símbolo tem base num losango, de registo geométrico, mas com referência orgânica, semelhante a gravuras registradas sobre a pele dos povos do Pacífico Sul. A tipografia de Papua também é neutra e geométrica, de modo a equilibrar a complexidade do símbolo, não desvirtuando a componente simbólica. A marca gráfica de Voke tem base tipográfica. O tipo utilizado não tem serifas e as características de diferenciação do tipo consistem em corte horizontal e uso de pesos light e bold, emitindo a irreverência e a ruptura que o DNA da marca pretende.

Apontando o componente cromático das marcas gráficas, nota-se que duas das marcas utilizam cores e duas não o fazem. A primeira situação dizem respeito Latitid e Voke, em que ambas ligam o seu DNA com as cores utilizadas. Em Latitid, os tons alaranjados e dourados condizem com a sofisticação e com o luxo propostos. Em Voke, o verde-água se liga ao frescor da juventude, todavia é uma cor diferenciada ao considerar-se o padrão posicionamento de luxo. Canté LX e a Papua utilizam preto e branco em suas marca gráficas e pertencem à segunda situação referida neste parágrafo. Pode-se dizer que esta é uma situação que é frequente em marcas de moda, pois a neutralidade do uso de preto e branco na marca gráfica possibilita a constante adaptação a tendências de moda

$\mathrm{Na}$ comunicação visual, onde os elementos se combinam, o registo de diferenciação entre as marcas estudadas também parece ser uma constante. Canté LX usa tipografia com o mesmo registo do tipo manuscrito encontrado na marca gráfica, denotando os mesmos princípios desta e reforçando a mensagem jovem e orgânica. Existe também um tipo sem serifas que complementa o sistema e não causa ruído na comunicação. Em Latitid, o registo é feito por um tipo sem serifas, neutro e elegante. A sua presença é minimalista, de modo a evidenciar a fotografia. Em Papua, a comunicação é feita pelo mesmo tipo que compõe a marca gráfica, garantindo as características referidas. Em Voke, as características da tipografia utilizada na comunicação são semelhantes a Papua e Latitid. Contudo, Voke apresenta outros tipos expressivos, causando a ruptura que a marca pretende transmitir. 
Pode-se dizer que nas marcas estudadas, a gama de cores auxiliares aumenta consideravelmente, provavelmente para estabelecer a ligação às tendências sazonais de moda aplicadas às coleções, mas também usadas em relação com o DNA. Canté LX utiliza superfícies brancas com variações de verde-água e corde-rosa (coral), reforçando o toque feminino e delicado da expressão visual. Há ainda a emergência de paletas em cores quentes. Em Latitid, a paleta cromática não é muito amplificada, optando-se pelas cores da marca gráfica em conjunto com o preto e branco, o verde-petróleo, o vermelho queimado e o azul-escuro que reforçam a noção de sofisticação. Papua investe em cores neutras e também apresenta cores com muita luz, as quais parecem introduzir as referências das tendências sazonais - assim como as cores quentes aplicadas por Canté LX. Voke e Papua têm a mesma perspectiva ao utilizar componente cromático reduzido e introduzir de alguns pontos de luz no ambiente em preto e branco.

No estilo fotográfico, a diferenciação entre as marcas é mantida, pois as imagens revelam as características presentes no DNA de cada uma. Em Canté LX, a figura humana surge muitas vezes de costas e em ambientes de praia, sempre com a presença de água e com registo de alto contraste. Latitid apresenta um estilo fotográfico ousado e com um toque de luxo, sem a presença da praia e ambiente cosmopolita com linhas modernas e minimalistas. Ambos os conceitos correspondem ao DNA da marca e criam analogias coerentes entre a marca e a imagem que a mesma projeta. Em Papua, o estilo fotográfico tem semelhanças com o criado por Latitid, por não utilizar a praia como cenário e apresentar elementos estranhos ao produto, mas que têm relação com o misticismo da marca. Já em Voke, a tipologia fotográfica é conceitual, ousada e sexy, onde a irreverência e o lifestyle cool que caracterizam o DNA da marca são elementos constantes.

\section{CONSIDERAÇÕES FINAIS}

Como conclusão deste trabalho de investigação é possível afirmar que existe utilidade na aplicação das linguagens de síntese visual/diagramas na leitura e diagnóstico da linguagem visual também em marcas de moda. A utilidade reside na sistematização dos elementos de análise das marcas gráficas e na capacidade que a representação visual sintetizada tem de favorecer a visão macro, permitindo perceber o sistema visual e captando a essência do seu clima; além de auxiliar a visão micro, proporcionando a percepção dos constituintes do referido sistema visual. Considera-se relevante frisar a valência de explicações sintetizadas sobre os elementos, a qual também implicou positivamente nas análises sobre as diferentes marcas.

Além disso, as sínteses visuais desenvolvidas para a análise das linguagens visuais das marcas abordadas são exemplos que refletem a relevância das ideias de Tufte. A comparação é facilitada pelo posicionamento físico semelhante dos elementos no suporte inserido na noção de paralelismo (TUFTE, 2010). Este paralelismo permite a comparação direta entre os vários sistemas visuais, o que facilita uma leitura das linguagens visuais das marcas e perceber em quais pontos existe diferenciação ou semelhança. Por exemplo, a justaposição das imagens possibilitou a identificação da adoção das mesmas tendências de moda por várias das empresas, além de características em comum que são particulares do segmento moda praia.

Essas análises podem ter seus resultados aplicados estrategicamente pelo reconhecimento do posicionamento, perfil e abordagem das diversas marcas do segmento - neste caso, o segmento de moda praia - optando por seguir ou divergir a linguagem visual das empresas concorrentes. As análises aqui identificadas podem gerar oportunidades de ação e gerenciamento da imagem das marcas deste e de demais segmentos de moda em relação à imagem propagada e à adoção de tendências de moda. 


\section{NOTAS}

[1] Marca gráfica é o elemento visual que sintetiza a personalidade da marca. Raposo (2008, p.26) a define como "um signo visual que poderá ser constituído por um logótipo, um sinal, um ícone ou um símbolo".

\section{REFERÊNCIAS}

CANTÊ. C2015. Disponível em:<http://cantelisboa.com>.Acesso em: set. 2015.

CARVALHAL, André. A moda imita a vida: como construir uma marca de moda. São Paulo: Estação das Letras e Cores, Rio de Janeiro: Ed. Senac Rio de Janeiro, 2014.

COSTA, Joan. La esquemática: visualizar la información. Madrid: Paidós Ibérica, 1998.

COBRA, Marcos. Marketing de serviço financeiro. 3a ed. São Paulo: Cobra, 2007.

MARTINS, José Roberto. Grandes Marcas, Grandes Negócios. Como as pequenas e médias empresas devem criar e gerenciar uma marca vencedora. $2 a$ ed. São Paulo: Global Brands, 2005.

MARTINS, José Roberto. Branding: Um manual para você criair, gerenciar e avaliar marcas. 3a ed. São Paulo: Global Brands, 2006.

OLINS, Wolff. The new guide to identity: How to create and sustain change through managing identity. London: Gower Publishing, 1995.

LATITID. C2015. Disponível em:< https://www.latitid.com>.Acesso em: out. 2015.

LUPTON, Ellen; PHILLIPS, Jeniffer Cole. Graphic Design: the new basics. New York: Princeton Architectural Press, 2008.

LUPTON, Ellen; PHILLIPS, Jeniffer Cole. Graphic Design Thinking: beyond brainstorming. New York: Princeton Architectural Press, 2011.

OLIVEIRA, Fernando. Diagramas \& Marcas: contributos sobre a utilização de diagramas na construção e análise do discurso visual das marcas. Lisboa: FA/UL, 2015.

PAPUA. C2015. Disponível em: <http://www.papua.pt>. Acesso em: out. 2015.

RAPOSO, Daniel. Design de Identidade e Imagem Corporativa: Branding, história da marca, gestão da marca, identidade visual corporativa. Castelo Branco: Edições IPCB, 2008.

TUFTE, Edward R. Beautiful Evidence. Connecticut: Graphics Press, 2007

TUFTE, Edward R, The visual display of quantitative information. $2 a$ ed. Connecticut: Graphics Press LLC, 2009.

TUFTE, Edward R. Visual explanations: images and quantities, evidence and narrative. Connecticut: Graphics Press, 2010.

RUÃO, Teresa. FARHANGMER, Minoo. A imagem de marca: análise das funções de representação e apelo no marketing das marcas, um estudo de caso. In: I Seminário de Marketing Estratégico e Planeamento. Actas... Portugal: Escola de 
Economia e Gestão, Universidade do Minho. 2000. pp. 1-11.

VOKE. C2015. Disponível em: <http://www.vokeswimwear.com>. Acesso em: out. 2015.

\section{Fernando Oliveira}

Fernando Oliveira é Doutorado em Design pela FA/UL e está no ensino superior há mais de 17 anos. Atualmente é Professor Auxiliar no IADE - $U$, coordenando os cursos de Mestrado em Design e Cultura Visual e Branding e Design de Moda. É Investigador e colaborador da unidade de investigação do IADE-U (UNIDCOM) e um participante activo na Orientação, e Co-orientação científica de Teses, Projectos e Relatórios de Estágio da instituição onde lecciona. Desempenha um papel relevante no apoio às actividades extra curriculares promovidas pela instituição e por Marcas como a QUIKSILVER, a EDP, a PT, a SOMELOS ou a SOCIEDADE PONTO VERDE. O percurso académico também é marcado pela autoria de workshops nacionais e internacionais tais como: "Diabrands - Diagramas como catalizadores do processo de construção da linguagem visual das marcas" (Brasil, 2013); "Caractividade" (Lisboa, 2013); "Diabrands - Diagrams as catalysts of construction process to create brands visual language" (Eslovénia, 2013); "Pictogram Stories" (Eslovénia, 2011); "Picto(move)grams" (Alemanha, 2009). Tem textos de autor publicados na área do Design visual/Branding/Sistemas de Identidade Visual, na área da Visualização da Informação e na área da Tipografia . Como Curador de Design gráfico foi autor da Exposição Type Studies — EXPERIMENTA DESIGN (Lisboa, 2013); da Exposição Type Studies - From class to public - IADE - CREATIVE

UNIVERSITY (Lisboa, 2013); e Curador do IADE - CREATIVE UNIVERSITY para o Concurso Internacional/publicação INDEX BOOK/SELECTION B (SCHOOLS (Barcelona, 2011). Como Designer independente é especialista em Branding/Sistemas de Identidade Visual/ Marcas e Sistemas de Visualização da Informação. Mantém uma relação forte com o mercado, com mais de 18 anos de experiência, desenvolvendo e dando consultoria em projectos, nacionais e internacionais, inseridos na primeira especialidade. Destes, podem destacar-se as Marcas e os Sistemas de Identidade Visual: MATTA SHAPES SURFBOARDS EUROPE (2014/15), IADE - CREATIVE UNIVERSITY (2009/14), SPO SURFBOARDS (2008/15; ATRIUM/PORTFOLIO MANAGER (2011/12), CORQUE/DESIGNING LIVING OBJECTS (2008 /10), FLANAGAN SURFBOARDS (2008/11 ) e AREIAS DO SEIXO (2009/12). Ligado às empresas de Design e Comunicação, como Director Criativo, trabalhou Marcas em várias áreas de negócio tais como: a PORTUGAL TELECOM, a VODAFONE, a AVIS, a ORACLE; a CLIX; a ONI; a ORATOL, as VIAGENS MARSANS, o CRÉDITO AGRÍCOLA/SEGUROS, O BANCO PRIVADO PORTUGUÊS, a OPCA, O GRUPO SOMAGUE, O INSTITUTO DE SEGUROS DE PORTUGAL; a HAWORTH EUROPE, O GRUPO IMPRESA, O GRUPO ABRANTINA, a SARRIÓ PAPEIS, o BENFICA, a JANSEN-CILAG, a RIOPELE e a REDUNICRE.

\section{Juliana Lima}

Juliana Lima Mendonça é graduada em Comunicação Social (Publicidade e Propaganda) e Pós-Graduada em Pesquisa de Mercado em Comunicação. Em 2015 conquistou o título de Mestre em Branding e Design de Moda pelas instituições IADE e UBI com a tese sob o tema: "A Linguagem Visual na Moda de Praia. Imagem de Marca, Análise do beachstyle, e estudo comparativo entre Portugal e Brasil". Atua há 10 anos no Mercado de Comunicação. Passou por Agências de Publicidade e Propaganda e Consultorias de Marca, entre elas a Interbrand, uma das principais consultorias de branding do mundo. Esteve envolvida na realização de projetos estratégicos para grandes marcas nacionais e globais durante mais de 3 anos na Interbrand Brasil, entretanto também realizou formações nos escritórios de Londres e Nova York. No Brasil foi Gerente de Contas na Cherry Plus, Agência de Comunicação com foco em Moda, Beleza e Lifestyle. E em Portugal, atuou como Digital Account de clientes na BYCom, Agência de Comunicação $360^{\circ}$. Atualmente é Marketing e Brand Manager da Morena Jambo, Marca Portuguesa de beachwear e fitness. 